\title{
Some Factors Affecting the Rooting of Softwood Cuttings of Japanese Persimmon
}

\author{
Takuya Tetsumura $^{1 *}$, Ryutaro Tao ${ }^{2}$ and Akira Sugiura ${ }^{2}$ \\ ${ }^{1}$ Experimental Farm, Graduate School of Agriculture, Kyoto University, Takatsuki, Osaka 569-0096 \\ ${ }^{2}$ Laboratory of Pomology, Graduate School of Agriculture, Kyoto University, Sakyo - ku, Kyoto 606-8502
}

\begin{abstract}
Summary
The factors influencing rooting of softwood cuttings of two cultivars, 'Jiro' and 'Nishimurawase', of Japanese persimmon (Diospyros kaki Thunb.) were studied. The cuttings from the root suckers of micropropagated trees rooted best, followed by those from the shoots of micropropagated trees and grafted trees in that order. Except for the cuttings from grafted trees, the shorter the cuttings, the higher the rooting percentage. When planted in late June, the single bud, leafy cuttings (leaf-bud cuttings) taken from the root suckers and treated with indole-3-butyric acid (IBA), 70\% or more rooted well. When planted in late July or late August, however, less than $40 \%$ of the leaf-bud cuttings rooted. Comparable cuttings without IBA treatment scarcely rooted when planted in late June, and did not root at all when planted in late July or late August. There was no significant difference in the rooting capacity between the two cultivars. Almost all leaf-bud cuttings from the root suckers survived during the experimental period (60 days), although those from the shoots of grafted trees died gradually; none of the $25-\mathrm{cm}$ cuttings from the root suckers survived 25 days after planting. The vascular cambium at the base of leaf-bud cuttings from the root suckers began to divide actively soon after planting. Callus formed in the phloem and cortex of the cut surface and developed extensively. However, active cell division was not observed at the bases of leaf-bud cuttings from the shoots of grafted trees nor $25-\mathrm{cm}$ cuttings from the root suckers. Initial cells of the adventitious root produced in the vascular cambium of the leaf-bud cuttings from the root suckers were first observed 20 days after planting; they developed to roots and emerged 30 days after planting.
\end{abstract}

Key Words: Diospyros kaki Thunb., Japanese persimmon, leaf-bud cutting, root sucker, softwood cutting.

\section{Introduction}

Japanese persimmon (Diospyros kaki Thunb.) is difficult to propagate by cuttings (Tao and Sugiura, 1992). Hence, there have been very few reports on the successful propagation with softwood cuttings in Japanese persimmon (Machida and Fujii, 1969; Murata et al., 1983; Tukamoto et al., 1959). In all their trials, etiolation of stock plants and blanching of cutting bases were required to obtain good rooting. These operations require time. Moreover, many cuttings died during their acclimatization to sunlight (Tukamoto et al., 1959), and only a few cuttings survived after rooting (Murata et al., 1983). Therefore, these propagation methods are uneconomical for commercial nursery plant production.

Recently, we succeeded in rooting the softwood

Received; June 19, 2000. Accepted; October 6, 2000.

${ }^{*}$ Corresponding author.

A part of this study was presented at the 1999 Spring Meeting and the 2000 Autumn Meeting of the Japanese Society for Horticultural Science.

This work was partially supported by Grant-in-Aid for Encouragement of Young Scientists to T. T. (no. 09760031 and 11760022) from the Ministry of Education, Science, Sports and Culture, Japan. cutting of a potentially dwarfing rootstock of Japanese persimmon by using root suckers (Tetsumura et al., 2000). When planted in late June or late July, almost all single bud, leafy stem (leaf-bud) cuttings rooted. Moreover, without any cumbersome operation, many suckers were induced annually so that hundreds of leafbud cuttings could be supplied for mass propagation. Therefore, we concluded that this propagation method would be promising for commercial use (Tetsumura et al., 2000). Thus we examined the effects of cutting length, IBA treatment, planting time, and cultivars on rooting of softwood cuttings taken from root suckers, whose mother trees had been micropropagated, compared with softwood cuttings taken from the shoots of micropropagated trees and grafted trees. Furthermore, we examined the histological changes in cutting bases in relation to rooting and survival of cuttings after planting.

\section{Materials and Methods}

\section{Exp. 1. Effect of cutting source and cutting length}

In late June, softwood cuttings were taken from the root suckers of micropropagated trees and the nonbearing shoots of micropropagated or grafted trees of 
'Nishimurawase'. These stock plants were prepared as described by Tetsumura et al. (2001). After the tender shoot apices of the root suckers and the shoots were discarded, three types of cuttings were collected from the root suckers and the non-bearing shoots including succulent shoots: 1) $25-\mathrm{cm}$ long cuttings with 5-7 buds and two halved terminal leaves; 2) $10-\mathrm{cm}$ long cuttings with 3-4 buds and two halved terminal leaves; 3 ) 3- to $4-\mathrm{cm}$ long single bud, leafy cuttings (leaf-bud cuttings). The cuttings prepared from the root suckers and the shoots were randomized because those from different positions on the root suckers had similar rooting percentages (Tetsumura et al., 2000). The bases of 10 cuttings of each type were dipped for $5 \mathrm{sec}$ in $3000 \mathrm{ppm}$ of $50 \%$ aqueous ethanolic IBA. After the rooting treatment, 20 cuttings were planted upright in a mixture of Kanuma soil (volcanic tuff, 2 to $3 \mathrm{~mm}$ diameter) and peat moss $(1: 1, \mathrm{v}: \mathrm{v})$ in 20 -liter plastic netted baskets (17 $\mathrm{cm}$ in depth). The baskets with cuttings were placed under a vaporized aluminum netting in a propagation frame covered with plastic film, which provided $24 \%$ irradiance (photosynthetically active radiation). The propagation frame was intermittently misted when the screen-balance switch became dry; it was ventilated with fans when the ambient air reached $35^{\circ} \mathrm{C}$. The survival and the rooting percentages and the number of roots per rooted cutting were recorded 60 days after planting.

\section{Exp. 2. Effect of cultivar, planting time, and IBA treatment}

In late June, late July, and late August, leaf-bud cuttings were collected from the root suckers of micropropagated trees of 'Nishimurawase' and 'Jiro'. The bases of 10 cuttings of each cultivar were dipped for 5 $\mathrm{sec}$ in a $3000 \mathrm{ppm}$ IBA in $50 \%$ aqueous ethanol solution. The bases of 10 comparable cuttings were soaked in 25 ppm IBA for $24 \mathrm{hr}$, while 10 untreated cuttings (control) were soaked in water for $24 \mathrm{hr}$. After treatment, the cuttings were planted in the same rooting medium and environmental conditions as in Exp. 1. The data were recorded 60 days after planting.

\section{Statistical analysis}

The $3 \times 3$ factorial with cutting source and cutting length as main effects was analyzed by analysis of variance (ANOVA) in Exp. 1 . The $2 \times 3 \times 3$ factorial with cultivar, planting time, and IBA treatment was analyzed by ANOVA in Exp. 2. All percentage data were subjected to arcsin transformation before subjected to ANOVA. In both experiments, the year $(1997,1998$, and 1999) served as the block (replication) only in the randomized complete-block experimental designs.

\section{Exp. 3. Changes in survival, rooting, and histology.}

On June 16, 1999, the leaf-bud and the $25-\mathrm{cm}$ cuttings from root suckers of micropropagated 'Jiro' trees and the leaf-bud cuttings from shoots of grafted 'Jiro' trees were subjected to the same rooting treatment, planted as in Exp. 1. On 0, 5, 10, 15, 20, 25, 30, 40, 50, and 60 days after planting, 10 cuttings of each type were dug up and examined for their survival and rooting. Then, their basal parts were excised, fixed in FAA (70\% ethanol: formalin: acetic acid, 90:5:5, v/v/v), treated with the softening agents according to Nakamura (1985), dehydrated in $\mathbf{n}$-butyl alcohol series, embedded in paraffin, and cut transversely into $10-14 \mu \mathrm{m} \mathrm{sec}-$ tions. The sections were stained with $0.05 \%$ toluidine blue $\mathrm{O}$ and observed under a light microscope.

\section{Results}

\section{Exp. 1. Effect of cutting source and cutting length}

The cuttings from the root suckers of micropropagated trees rooted best; cuttings from the shoots of micropropagated trees rooted better than those from grafted trees (Table 1). The shorter the cuttings, the higher was the rooting percentage, except for the cuttings from grafted trees, and the survival percentage $(y)$ correlated with the rooting percentage $(x)[y=1.06 x-41, r=0.76]$. The cutting groups with higher rooting percentage (Table 1) had more roots (data not shown) establishing a linear relationship expressed by the equation $y=4.77 x+11.43$ $(r=0.74)$, in which $y$ is the rooting percentage and $x$ is the roots per cutting.

Table 1. Effects of cutting source and cutting length on the rooting percentage of the softwood cuttings of 'Nishimurawase' Japanese persimmon, which were treated with $3000 \mathrm{ppm}$ IBA solution for $5 \mathrm{sec}$ (Exp. 1).

\begin{tabular}{lcc}
\hline Cutting source & $\begin{array}{c}\text { Cutting length } \\
(\mathrm{cm})\end{array}$ & $\begin{array}{c}\text { Rooting } \\
(\%)\end{array}$ \\
\hline Root suckers of micropropaged & 25 & 30 \\
& 10 & 43 \\
Shoots of micropropageted trees & $3-4^{z}$ & 70 \\
& 25 & 13 \\
Shoots of grafted trees & 10 & 17 \\
& $3-4^{z}$ & 37 \\
& 25 & 10 \\
& 10 & 7 \\
& $3-4^{z}$ & 10
\end{tabular}

Significance

Cutting source(CS)

Cutting length(CL)

$\mathrm{CS} \times \mathrm{CL}$

\footnotetext{
${ }^{z}$ Leaf-bud cuttings.

${ }^{\mathrm{y}} \mathrm{ns},{ }^{*},{ }^{* * *}:$ nonsignificant or significant at $P<0.05$ or 0.005 , respectively.
} 
Table 2. Effects of cultivar, planting time, and IBA treatment on the rooting percentage of leaf - bud cuttings from root suckers of micropropagated Japanese persimmon (Exp. 2).

\begin{tabular}{|c|c|c|c|c|}
\hline \multirow{3}{*}{ Cultivar } & \multirow{3}{*}{ Planting time } & \multicolumn{3}{|c|}{ Rooting(\%) } \\
\hline & & \multicolumn{3}{|c|}{ Method of rooting treatment } \\
\hline & & Control & $\begin{array}{l}\text { IBA } 25 \mathrm{ppm} \\
\text { for } 24 \mathrm{hr}\end{array}$ & $\begin{array}{c}\text { IBA } 3000 \mathrm{ppm} \\
\text { for } 5 \mathrm{sec}\end{array}$ \\
\hline \multirow[t]{3}{*}{ Nishimurawase } & Late-June & 13 & 73 & 80 \\
\hline & Late-July & 0 & 20 & 37 \\
\hline & Late- August & 0 & 10 & 17 \\
\hline \multirow[t]{3}{*}{ Jiro } & Late-June & 10 & 77 & 70 \\
\hline & Late-July & 0 & 3 & 30 \\
\hline & Late- August & 0 & 7 & 17 \\
\hline \multicolumn{5}{|l|}{ Significance } \\
\hline \multicolumn{2}{|l|}{ Cultivar (CV) } & $\mathrm{ns}^{\mathrm{z}}$ & & \\
\hline \multicolumn{2}{|c|}{ Planting time (PT) } & $* * *$ & & \\
\hline \multicolumn{2}{|c|}{ Method of rooting treatment (RT) } & $* * *$ & & \\
\hline \multicolumn{2}{|l|}{$\mathrm{CV} \times \mathrm{PT}$} & ns & & \\
\hline \multicolumn{2}{|l|}{$\mathrm{PT} \times \mathrm{RT}$} & $* *$ & & \\
\hline \multicolumn{2}{|l|}{$\mathrm{RT} \times \mathrm{CV}$} & ns & & \\
\hline \multicolumn{2}{|c|}{$\mathrm{CV} \times \mathrm{PT} \times \mathrm{RT}$} & $* *$ & & \\
\hline
\end{tabular}

${ }^{2} \mathrm{~ns},{ }^{* *},{ }^{* * *}:$ nonsignificant or significant at $P<0.01$ or 0.005 , respectively.

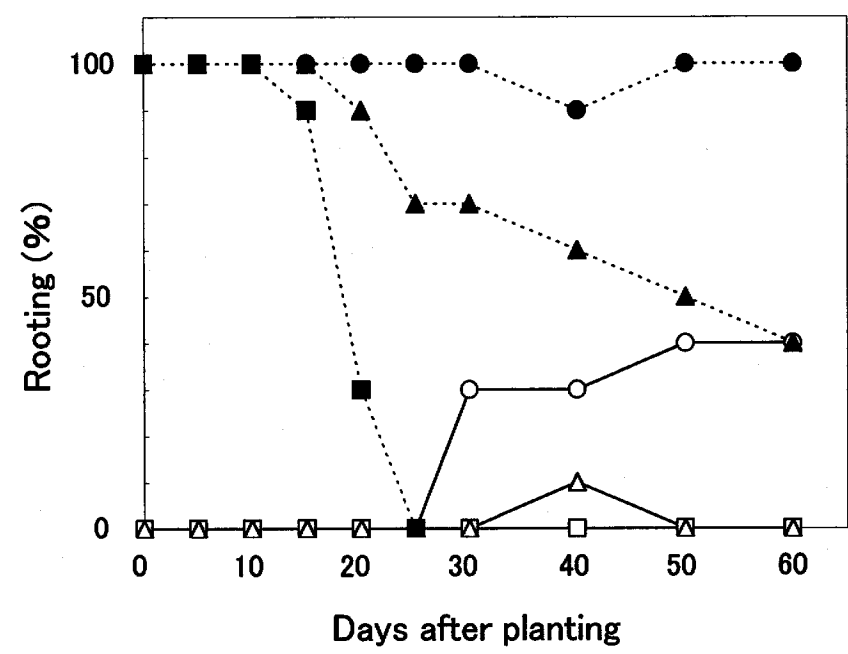

Fig. 1. Changes in rooting percentage (open symbols) and survival rate (solid symbols) of the softwood cuttings of 'Jiro' Japanese persimmon, which were treated with 3000 ppm IBA solution for $5 \mathrm{sec}$ (Exp. 3). $\bigcirc, 0$ : Leaf-bud cuttings from root suckers of micropropagated trees. $\square$, : $25-\mathrm{cm}$ cuttings from root suckers of micropropagated trees. $\triangle, \boldsymbol{\Delta}$ : Leaf-bud cuttings from shoots of grafted trees.

\section{Exp. 2. Effect of cultivar, planting time, and IBA treatment}

The planting time and IBA treatment had significant effects on the rooting percentages, and there was a significant interaction between them (Table 2). When the cuttings were planted in late-June, IBA treatment yielded more than $70 \%$ with roots. However, there was no distinct difference in rooting percentages between the treatments with $25 \mathrm{ppm}$ IBA for $24 \mathrm{hr}$ and $3000 \mathrm{ppm}$ IBA for $5 \mathrm{sec}$. When the cuttings were planted in late July or late August, the rooting percentages were much lower than those in late-June; the cuttings treated with $3000 \mathrm{ppm}$ IBA rooted better than did those with $25 \mathrm{ppm}$ IBA. The control cuttings produced few roots when planted in late June and no roots when planted in late July or late August. There was no significant difference in rooting percentage between the two cultivars. There was the same linear relationship between the rooting percentage $(y)$ and the number of roots per rooted cutting ( $\mathrm{x}$ ) as in Exp. 1 ['Jiro': $\mathrm{y}=7.13 \mathrm{x}+22.35, \mathrm{r}=$ 0.73; 'Nishimurawase': $y=9.49 x+7.59, r=0.83$ ].

\section{Exp. 3. Changes in survival, rooting, and histology}

Almost all leaf-bud cuttings from the root suckers of micropropagated trees survived 60 days after planting; none of the $25-\mathrm{cm}$ cuttings survived 25 days after planting (Fig. 1). The leaf-bud cuttings from the shoots of grafted trees died gradually, but $40 \%$ of them survived 60 days after planting. Roots of leaf-bud cuttings taken from the root suckers emerged 30 days after planting; the final rooting percentage was lower than that in Exp. 2. Only a few leaf-bud cuttings derived from the shoots of grafted trees rooted, and none of the 25 - cm cuttings did.

At planting time, there was no root primordium in the cuttings and no apparent difference in histology between the cuttings from the root suckers and from the shoots, except for more distinct development of sclerenchyma in the latter (Fig. 2A-B). Vascular cambium of the leafbud cuttings from the root suckers became active soon 


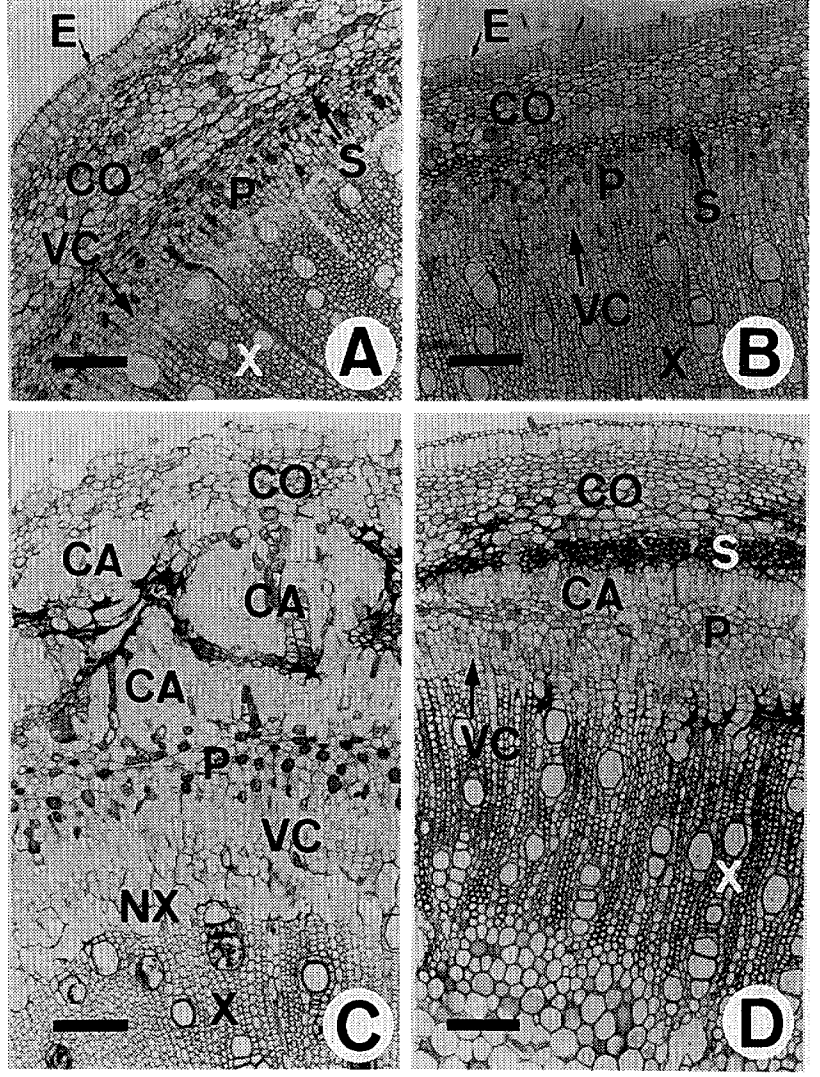

Fig. 2. Photomicrographs of sections of basal parts of the softwood cuttings of 'Jiro' Japanese persimmon, which were treated with $3000 \mathrm{ppm}$ IBA solution for $5 \mathrm{sec}$. (A) 0 day after planting of leaf-bud cutting from the root sucker of micropropagated tree, showing few sclerenchymatous cells inside cortex. (B) 0 day after planting of leaf-bud cutting from the shoot of grafted tree, showing a continuous sclerenchymatous ring inside cortex. (C) 15 days after planting of leaf-bud cutting from the root sucker. Note the callus developing extensively in the phloem and cortex and new xylem forming inside vascular cambium. (D) 15 day after planting of leaf-bud cuttings from the shoot, showing callus forming between a thick sclerenchymatous cell layer and phloem. Abbreviations: callus (CA), cortex (CO), epidermis (E), newly formed xylem (NX), phloem (P), sclerenchyma (S), vascular cambium (VC), xylem (X). All scale bars $=$ $0.2 \mathrm{~mm}$.

after planting and formed new xylem. The basal part of the cuttings formed callus tissue in the phloem and cortex, which eventually broke through the cortex and epidermis (Fig. 2C). The basal tissues of the leaf-bud cuttings taken from shoots were seemingly inactive, but some began to form callus 15 days after planting (Fig. 2D). Tissues of the $25-\mathrm{cm}$ cuttings remained inactive, collapsing gradually after planting.

Adventitious root initials, which could be readily distinguished from callus cells, differentiated in the vascular cambium; those just above the cut surface of leaf-bud cuttings derived from root suckers were visible 20 days after planting (Fig. 3A). They developed into
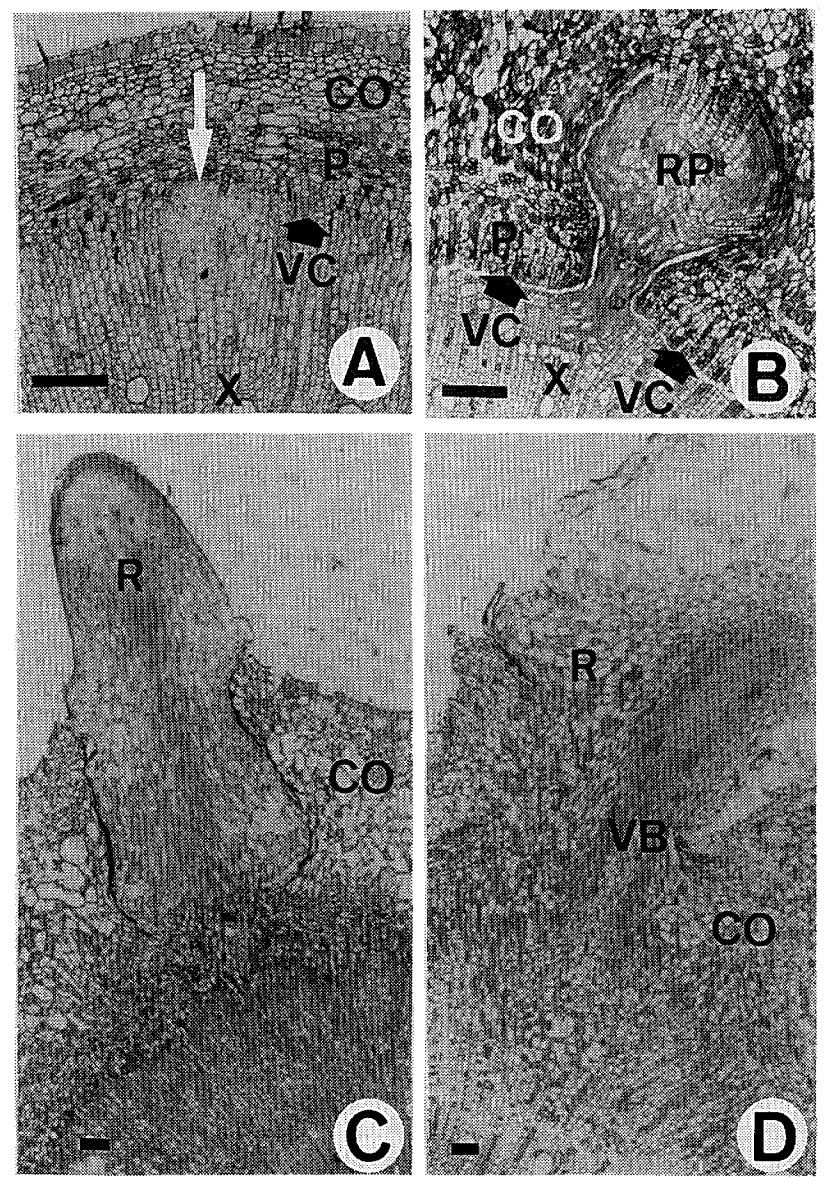

Fig. 3. Photomicrographs of sections of basal parts of leafbud cuttings derived from the root suckers of 'Jiro' Japanese persimmon and treated with $3000 \mathrm{ppm}$ IBA solution for $5 \mathrm{sec}$. (A) Differentiation of distinct adventitious, root initials in the vascular cambium (a white arrow) 20 days after planting. (B) A root primordium penetrating into phloem and cortex 25 days after planting. (C) An emerging root 30 days after planting. (D) Completion of vascular connections between young root and cutting vascular systems 40 days after planting. Abbreviations: cortex (CO), phloem (P), root (R), root primordium (RP), vascular bundle (VB), vascular cambium (VC), xylem (X). All scale bars $=0.2 \mathrm{~mm}$.

root primordia penetrating into phloem and cortex (Fig. 3B). Adventitious roots broke through the epidermis and emerged 30 days after planting (Fig. 3C), while vascular connections developed between roots and cuttings (Fig. 3D).

\section{Discussion}

Previously, we found that shorter softwood cuttings and hardwood cuttings from root suckers rooted well (Tetsumura et al., 2000; Tetsumura et al., 2001). Obtaining a high percentage of rooted softwood cuttings demonstrated that own-rooted trees of scion cultivars can be produced easily, inexpensively, and abundantly 
by using root suckers. Micropropagation is an efficient method of vegetative propagation of persimmon compared with the conventional method of grafting onto seedlings (Tao and Sugiura, 1992). The own-rooted and micropropagated Japanese persimmon trees grew more vigorously than did the conventionally grafted ones (Tetsumura et al., 1999). It is still necessary, however, to evaluate the field performance of trees propagated by cuttings.

Generally, the use of leaf-bud cuttings made rapid propagation from a limited number of stock plants possible (Stoutemyer et al., 1933). In this study, the number of cutting per replication was small because the stock plants were limited and most of them were used for the $25-\mathrm{cm}$ long cuttings. The leaf-bud cuttings with high rooting percentage will make a mass propagation from a limited number of stock plants possible.

The phenomenon that the cuttings from the micropropagated trees rooted better than did those from grafted trees has been reported for many species; it was assumed that this improvement in rooting is attributable to rejuvenation (Hogue and Neilsen, 1991; Howard et al., 1989; Jones and Webster, 1989; Marks, 1991; Plietzsch and Jesch, 1998). Hence, Howard (1987) concluded that micropropagation would produce stock plants as a source of cuttings. The reason for the better rooting of cuttings from the root suckers of micropropagated trees than from the shoots of micropropagated trees is presumably that the former retain more juvenile characteristics than the latter (Del Tredici, 1995).

Planting time is important for the rooting of cuttings as with some trees and shrubs (Howard, 1996; Murai et al., 1999; Singh et al., 1957; Tetsumura et al., 2000). Cuttings from root suckers of 'Nishimurawase' and 'Jiro' rooted better when planted in June than in July or August. Similar results with ornamental shrubs (Howard, 1996) and the dwarfing rootstock for Japanese persimmon (Tetsumura et al., 2000) seem to indicate that the growth rate of the root suckers affected the rooting of the cuttings. As sucker growth rate decreased in late July, so did their rooting ability.

IBA treatment was a prerequisite for inducing roots on softwood cuttings from the root suckers, although the treatment did not improve rooting of the hardwood cuttings derived from the etiolated root suckers, which already had root primordia before the IBA treatment (Tetsumura et al., 2001). IBA treatment is considered to promote the differentiation of root primordia in the Japanese persimmon softwood cuttings as well as in the other fruit tree species (Gemma et al., 1983; Murai et al., 1999). Although successful, further study on IBA treatment method is necessary, the optimum IBA concentration to induce rooting in the cuttings was not the main objective in this study.

Survival of cuttings from root suckers and shoots of micropropagated trees is a function of root formation which, in turn, depends on high humidity in the propa- gation frame as we found with our trial with dwarfing rootstock for Japanese persimmon (Tetsumura et al., 2000). Hence, to improve rooting of the cuttings, their juvenility, length of the cuttings, planting time and the environmental condition for inducing cell division in the vascular cambium are essential.

This is the first report showing the histological process of adventitious root formation in the softwood cuttings of Japanese persimmon. The origin of root primordia is in the vascular cambium, as was previously reported with European chestnut cuttings (Castanea sativa Mill.) (Vieitez et al., 1980). However, hardwood cuttings from the etiolated root suckers of Japanese persimmon produced root primordia in the phloem (Tetsumura et al., 2001). Similarly, root primordia of etiolated and girdled cuttings of European chestnut shoots also originated in the phloem (Biricolti et al., 1994). The origin of root primordia might vary with the treatment for root induction, i. e., IBA treatment or etiolation treatment.

Finally, our method for softwood cutting propagation holds promise for commercial use because it is more efficient than previous methods for softwood cutting propagation of Japanese persimmon (Machida and Fujii, 1969; Murata et al., 1983; Tukamoto et al., 1959); almost all cuttings survived after acclimatization to sunlight. Moreover, our method may be applicable to many other persimmon cultivars.

\section{Acknowledgements}

Thanks are due to $\mathrm{H}$. Minami and $\mathrm{H}$. Wakahara for the maintenance of trees and root suckers.

\section{Literature Cited}

Biricolti, S., A. Fabbri, F. Ferrini and P. L. Pisani. 1994. Adventitious rooting in chestnut: an anatomical investigation. Scientia Hortic. 59: 197- 205.

Del Tredici, P. 1995. Shoot from roots: a horticultural review. Arnoldia. 55: 11-19.

Gemma, H., K. Fujimaki, M. Ishida and Y. Sobajima. 1983. Anatomical studies on initiation and development of roots in wild peach stem cuttings. J. Japan. Soc. Hort. Sci. 52: 256-265 (In Japanese with English summary).

Hogue, E. J. and D. Neilsen. 1991. Rapid production methods for Ottawa-3 rootstock and branched apple nursery stock. HortScience 26: 1416-1419.

Howard, B. H. 1987. Propagation. p.29-77. In: R. C. Rom and R. F. Carlson (eds.). Rootstocks for fruit crops. Jon Wiley \& Sons, New York.

Howard, B. H. 1996. Relationships between shoot growth and rooting of cutting in three contrasting species of ornamental shrub. J. Hort. Sci. 71: 591-605.

Howard, B. H., O. P. Jones and J. Vasek. 1989. Long-term improvement in the rooting of plum cuttings following apparent rejuvenation. J. Hort. Sci. 64: 147-156.

Jones, O. P. and C. A. Webster. 1989. Improved rooting from conventional cutting taken from micropropagated 
plants of Pyrus communis rootstocks. J. Hort. Sci. 64: $429-434$.

Machida, H. and T. Fujii. 1969. Studies on the promotion of the rooting in cuttings and the formation of adventitious roots. Memoirs Fac. Agr. Tokyo Univ. Educ. 15: 48-92 (In Japanese with English summary).

Marks, T. R. 1991. Rhododendron cuttings. I. Improved rooting following 'rejuvenation' in vitro. J. Hort. Sci. 66: $103-111$.

Murata, R., R. Oishi and H. Okishima. 1983. Characteristics and cultural value of dwarf and normal Nishimurawase persimmon. (3) Softwood cutting by etiolation method. Bul. Shiga Agr. Expt. Sta. 25: 71-75 (In Japanese with English summary).

Murai, Y., H. Harada, R. Mochioka, T. Ogata, S. Shiozaki, S. Horiuchi, H. Mukai and T. Takagi. 1999. Relationships between rooting in softwood cuttings of mume (Prunus mume Sieb. et Zucc.) and sorbitol in shoots. J. Japan. Soc. Hort. Sci. 68: 648-654 (In Japanese with English summary).

Nakamura, T. 1985. Double softening treatment for cuttings hard tissues of herbaceous plants by paraffin method. Rep. Tohoku Br. Crop Sci. Soc. Japan 28: 151-154 (In Japanese with English summary).

Plietzsch, A. and H.-H. Jesch. 1998. Using in vitro propagation to rejuvenate difficult-to-root woody plants. Comb. Proc. Intl. Plant Prop. Soc. 48: 171- 176.

Singh, S. M., R. J. Garner and E. S. J. Hatcher. 1957. The behaviour of softwood cuttings of apple in the open under intermittent mist and in a closed propagation frame. J. Hort. Sci. 32: 239-247.
Stoutemyer, V. T., T. J. Maney and B. S. Pickett. 1933. A rapid method propagating raspberries and blackberries by leaf-bud cuttings. Proc. Amer. Soc. Hort. Sci. 30: 278-282.

Tao, R. and A. Sugiura. 1992. Micropropagation of Japanese persimmon (Diospyros kaki L.). p.424-440. In: Y.P.S. Bajaj (ed.). Biotechnology in agriculture and forestry, 18: High-tech and micropropagation II. SpringerVerlag, Berlin.

Tetsumura, T., R. Tao and A. Sugiura. 2000. Single-node stem cuttings from root suckers to propagate a potentially dwarfing rootstock for Japanese persimmon. HortTechnology 10: 776-780.

Tetsumura, T., R. Tao and A. Sugiura. 2001. Factors affecting rooting of Japanese persimmon hardwood cutting. $\mathbf{J}$. Japan. Soc. Hort. Sci. 70:(in press).

Tetsumura, T., R. Tao and H. Yukinaga. 1999. Orchard growth, flowering, and fruiting of micropropagated Japanese persimmon trees. J. Hort. Sci. Biotechnol. 74: $251-253$.

Tukamoto, M., T. Ichii, M. Sawano and T. Osaki. 1959. Studies on the rooting of Japanese persimmon stem cuttings. (I) Effects of etiolation on the rooting of softwood cutting in Japanese persimmon trees (Diospyros kaki LINN. f.). Sci. Rpt. Hyogo Univ. Agr. 4: 60-64 (In Japanese with English summary).

Vieitez, A. M., A. Ballester, M. T. Garcia and E. Vieitez. 1980. Starch depletion and anatomical changes during the rooting of Castanea sativa Mill. cuttings. Scientia Hortic. 13: $261-266$.

\title{
カキ緑枝挿しの発根に及ぼす要因について \\ 鉄村环哉 ${ }^{1} \cdot$ 田尾龍太郎 ${ }^{2} \cdot$ 杉浦 $^{\text {明 }}{ }^{2}$ \\ ${ }^{1}$ 京都大学大学院農学研究科附属農場 569-0096 大阪府高柣市八丁畷町 12-1 \\ 2 京都大学大学院農学研究科 606-8502 京都市左京区北白川追分町
}

\begin{abstract}
摘 要
カキ2品種 (“次郎’および ‘西村早生’)の緑枝掩しの発 根に及ぼす種々の要因について調査した。組織培養樹の ひこばえ由来の挿し穂は, 他の材料由来の挿し穂よりも 良好に発根した. 組織培養樹の新しょう由来の挿し穂は, 実生台接木樹の新しょう由来のものより良好に発根した. 接木樹由来の挿し穂を除いて, 短い挿し穂ほど, 発根率 は高かった．ひこばえ由来の葉芽捰し穂にIBA処理を行 い，6月下旬に挿し木すると，70\%の発根率が得られた. しかし，7月下旬あるいは 8月下旬に挿し木すると，発根 率は 40\% 未満であった. IBA処理を行わなかった葉芽挿 し穂は，6月下旬に挿すとほとんど発根せず，7月下旬あ るいは8月下旬に挿すと全く発根しなかった。発根率に

由来の葉芽扦し穂のほどんどは生存していたが, 接木樹 の新しょう由来の葉芽插し穂は徐々に枯死していった. また, ひこばえ由来の長さ $25 \mathrm{~cm}$ の挿し穂は, 挿し木後 25 日目までにすべて枯死した。ひこばえ由来の葉芽捜し穂 の維管束形成層は挿し木後, すぐに細胞分裂を始めた. また，カルス組織が師部や皮層で形成され，広範囲に発 達した。しかし，接木樹の新しょう由来の葉芽挿し穂や ひこばえ由来の長さ $25 \mathrm{~cm}$ の挿し穂では活発な細胞分裂は 観察されなかった。 ひこばえ由来の葉芽挿し穂では, 維 管束形成層内に分化した不定根始原細胞群が, 挿し木後 20日目に始めて観察され, 捜し木後 30 日目には挿し穂の 外部に根となって出現した。
\end{abstract} 品種間差は認められなかった，挿し木実験中，ひこばえ 